\title{
Ekstrak Air Rumput Kebar (Biophytum petersianum Klotzch) sebagai Penghambat Perkembangan Telur Cacing Gastrointestinal Ruminansia Secara in Vitro
}

\author{
Kebar Grass (Biophytum petersianum klotzch) Extract as in vitro ruminant \\ gastrointestinal worms Egg's Growth Deterrent.
}

\author{
Alnita Baaka, Isti Widayati, Noviyanti \\ Fakultas Peternakan, Universitas Papua, Manokwari, Papua Barat \\ Email:alnita.baaka@gmail.com
}

\begin{abstract}
Gastrointestinal worm disease in cattle is scathing for the breeder's as it lowers cattle's productivity and inflict major economic loss. Furthermore, the interraction between cattle, man and the environment might bring out the risk of zoonotic diseases (diseases which can spread between man and animals). Kebar grass contains phytochemical elements such as alkaloid, saponin, tanin, glycoside and flavonoid. Those elements have the potential as an alternate anthelmentic in the effort to utilize the endemic biodiversities of Papua. This research is performed at Faculty of Animal Husbandry Animal Health Laboratory and Faculty of Math and Natural Science Microbiology Laboratory of Universitas Papua, for 8 months. The leaves and the stems of the kebar grass were collected and stored at room temperature. The Kebar grass extract was divided into 3 parts, i.e. fresh extract, wind dried extract and sun dried extract. Fresh fecal samples were collected and examined with the native method. The samples where nematodes eggs are found is treated with kebar grass extract. As a comparison, positive control is made with oxfendazole and negative control is made nematodes larvae fertilization. Fecal cultures and grass extract mixture is left alone for 7 days in room temperature and examined under microscope with 400x fortification to see whetner there is any development of the nematodes' eggs. The obstained data is analyzed by tabulation and descriptive method. The result is the samples mixed with kebar grass extract show no development of nematodes' egg. As a comparison, the negative control which is observed with baerman method shows development of nematodes' eggs. It can be concluded that the effect of kebar grass extract can deters nematodes' egg development.
\end{abstract}

Key words : nematodes egg, gastrointestinal, kebar grass (Biophtyum petersianum Klotzch), liquid extract, anthelmentik

\begin{abstract}
Abstrak
Penyakit cacing gastrointestinal pada ternak sapi sangat merugikan peternak karena dapat menurunkan produktivitas ternak dan menimbulkan kerugian ekonomi yang sangat besar. Selain itu, adanya interaksi antara ternak, manusia dan lingkungan memunculkan kemungkinan timbulnya bahaya penyakit zoonosis (penyakit yang dapat menular antara ternak dan manusia). Rumput Kebar (Biophtyum petersianum Klotzch) mengandung bahan fitokimia seperti alkaloid, saponin, tanin, glikosida dan flavonoid. Bahan-bahan tersebut memiliki potensi sebagai anthelmintik alternatif dalam upaya pemanfaatan keanekaragaman hayati endemik Papua. Penelitian ini dilakukan di Laboratorium Kesehatan Hewan FAPET dan Laboratorium Mikrobiologi FMIPA UNIPA Manokwari, selama 8 bulan. Bagian daun dan batang dari rumput kebar dikoleksi kemudian disimpan pada suhu ruang. Ekstrak air rumput kebar dibagi 3 yaitu ekstrak rumput kebar segar, kering angin dan kering jemur di bawah matahari. Sampel feses segar dikoleksi dan diperiksa dengan metode natif. Feses yang ditemukan telur cacing nematoda diberi perlakuan dengan ekstrak air rumput kebar. Sebagai pembanding, dibuat kontrol positif dengan oxfendazole dan kontrol negatif dengan pemupukan larva cacing. Kultur feses dan ekstrak dibiarkan selama 7 hari pada suhu ruangan, dan diperiksa menggunakan mikroskop cahaya perbesaran $400 \mathrm{x}$, untuk melihat ada tidaknya perkembangan telur cacing. Data yang diperoleh dianalisis secara tabulasi dan deskriptif. Hasil yang diperoleh yakni pada ekstrak air rumput kebar segar dan kering angin juga kontrol positif tidak ditemukan adanya perkembangan telur cacing, sebagai pembanding pada kontrol negatif dengan menggunakan metode baerman ditemukan adanya larva cacing yang berkembang. Sehingga dapat disimpulkan bahwa pengaruh ekstrak air rumput kebar dapat menghambat perkembangan telur cacing nematoda.
\end{abstract}

Kata Kunci: Telur nematoda, gastrointestinal, rumput Kebar (Biophtyum petersianum Klotzch), ekstrak air, anthelmintik 


\section{Pendahuluan}

Penyakit cacing gastrointestinal pada ternak sapi sangat merugikan peternak dengan menurunkan produktivitas ternak dan menimbulkan kerugian ekonomi yang sangat besar. Selain itu, adanya interaksi antara ternak, manusia dan lingkungan memunculkan kemungkinan timbulnya bahaya penyakit ini bersifat zoonosis (penyakit yang dapat menular antara ternak dan manusia).

Di Indonesia angka kejadian cacingan pada sapi sebagai salah satu jenis ternak sangat bervariasi, yaitu sebesar 96\% di Padang (Harminda, 2011), 61,46\% di Palembang (Nofyan et al., 2010), 75\% di Kabupaten Gowa Sulawesi Selatan (Purwanta et al., 2009), 44,23\% di Kabupaten Manokwari (Junaidi et al., 2014), 47\% di eks-Karesidenan Banyumas (Munadi, 2011), 62,5\% di Kabupaten Purworejo, 70,7\% di Kabupaten Magelang, 71,1\% di Kabupaten Boyolali, 66,8\% di Kabupaten Klaten, 57,4\% di Kabupaten Wonogiri, 58,6\% di Kabupaten Karanganyar, 64\% di Kabupaten Temanggung dan 69,3\% di Kabupaten Batang (Purwaningsih, 2013).

Berdasarkan pengetahuan tentang siklus hidup cacing baik itu di hewan/manusia sebagai inang (hospes), hewan/manusia sebagai perantara (reservoir) dan lingkungan, maka cara yang paling tepat untuk mengurangi ataupun mengeleminir infeksi cacing gastrointestinal adalah dengan memutus atau mengganggu siklus hidup cacing. Pemberian obat cacing komersil merupakan sampai saat ini masih digunakan untuk memutus atau mengganggu siklus hidup cacing. Pada prakteknya, pemberian obat cacing komersil ini memiliki beberapa kelemahan antara lain harga yang tidak terjangkau oleh peternak, serta komponen obat cacing mengandung beberapa residu kimia yang bersifat toksik (Kaemmerer dan Butenkotter, 1973). Penggunaan obat cacing pada hewan ternak menyebabkan residu kimia terdapat pada daging hewan. Apabila pemberiannya dalam waktu singkat sebelum hewan dipotong, residu tersebut akan membahayakan kesehatan manusia apabila daging tersebut dikonsumsi.

Pengobatan anthelmentik menggunakan tanaman merupakan produk natural, ramah lingkungan dan dapat dijangkau dengan harga yang murah. Pengobatan menggunakan tanaman saat ini merupakan salah satu topik penelitian yang saat ini sangat didukung oleh berbagai lembaga penelitian di berbagai negara karena mampu mengangkat nilai-nilai keanekaragaman hayati dan konservasi. Penelitian tentang tanaman herbal sebagai anthelmentik dan obat-obatan lainnya bagi hewan di Tanah Papua sendiri masih sangat dibutuhkan mengingat kurangnya petugas kesehatan hewan di berbagai daerah serta kondisi geografis yang sangat sulit dijangkau untuk pengobatan konvensional dari petugas kesehatan hewan.

Rumput Kebar (Biophtyum petersianum Klotzch) sebagai tanaman endemik Papua telah diteliti memiliki berbagai khasiat diantaranya sebagai antiinflamasi, imunostimulan, serta mampu meningkatkan performa reproduksi hewan (Sadsoeitoeboen, 2005; GrØnhaug, et al.,2008; Unitly, 2013). Di negara Afrika, tumbuhan ini digunakan sebagai obat luka karena sengatan dan gigitan ular, serta sebagai obat sakit perut (Inngjerdingen, et al., 2004; 2006; 2008).

Beberapa jenis senyawa metabolit sekunder yang terdapat pada tanaman yang memiliki efek anthelmentik yaitu alkaloid, minyak atsiri, flavonoid, saponin, enzim serta tanin terkondensasi. Senyawa ini terbukti secara ilmiah mampu bekerja secara in vitro dan in vivo untuk menghambat pertumbuhan berbagai stadium cacing atau membunuh cacing 
dewasa gastrointestinal pada ternak. Beberapa komponen tanaman tersebut seringkali lebih efektif ketika bekerja secara sinergis sebagai anthelmentik (Hrckova, et al., 2013). Adanya kandungan fitokimia seperti alkaloid, saponin, tanin, dan flavonoid yang terkandung dalam rumput kebar, diharapkan memiliki potensi sebagai anthelmentika alternatif serta merupakan salah satu upaya dalam pemanfaatan keanekaragaman hayati endemik di Papua. Tujuan dari penelitian ini adalah melihat pengaruh ekstrak air rumput kebar terhadap daya hambat pertumbuhan cacing gastrointestinal pada ternak. Diperoleh ekstrak air rumput kebar yang dapat menghambat pertumbuhan cacing gastrointestinal pada ternak bagi khasanah pengembangan ilmu pengetahuan khususnya bagi peternak-peternak yang berdomisili di Papua.

\section{Materi dan Metode}

\section{Tempat Penelitian}

Sampel yang diambil adalah sampel Rumput Kebar segar. Pengambilan sampel rumput Kebar segar dilakukan di Distrik Kebar yang berjarak $150 \mathrm{~km}$ Barat Daya dari kota Manokwari yang dapat ditempuh dengan pesawat udara selama 45 menit atau dengan kendaraan darat selama 10 - 12 jam. Pengambilan sampel feses dilakukan dengan mengambil sampel feses segar dari sapi pada Distrik Prafi, Kabupaten Manokwari. Percobaan in vitro dilaksanakan di laboratorium Kesehatan Hewan FAPET dan Laboratorium Mikrobiologi FMIPA, Universitas Papua.

\section{Pengumpulan dan penyediaan Rumput Kebar}

Bahan yang digunakan adalah Rumput Kebar segar. Sebelum digunakan dan dibuat ekstrak, rumput dibersihkan. Bagian rumput yang digunakan adalah daun, batang, dan akar. Selanjutnya sampel dibagi menjadi tiga, untuk dibuat ekstrak yakni rumput kebar segar, kering angin,dan kering dengan penjemuran dibawah sinar matahari.

\section{Pembuatan ekstrak Rumput Kebar segar}

Sebanyak 50 gram Rumput Kebar segar yang belum lama dicabut dicuci dengan air hingga bersih. Seluruh bagian rumput (daun, batang, dan akar) direndam dalam air $200 \mathrm{ml}$ yang bersuhu $90^{\circ} \mathrm{C}$. Rumput dan air diaduk hingga dingin, kemudian diblender. Campuran rumput dan air disaring, supernatan disimpan pada refrigerator suhu $4^{\circ} \mathrm{C}$ untuk penggunaan selanjutnya (Kardel, et. al., 2013).

\section{Pembuatan ekstrak Rumput Kebar kering angin}

Rumput Kebar segar dikeringkan pada suhu kamar $\left(25-30^{\circ} \mathrm{C}\right)$ selama 7 hari. Setiap dua kali sehari rumput dibolak-balik untuk mempercepat proses pengeringan. Setelah 7 hari, sebanyak 50 gr rumput kebar yang telah dikeringkan dijadikan serbuk dengan menggunakan blender. Serbuk rumput kebar direndam dalam $400 \mathrm{ml}$ air lalu diinkubasi pada suhu $90^{\circ} \mathrm{C}$ selama $2 \mathrm{jam}$. Setelah dingin, larutan ini kemudian disimpan pada refrigerator suhu $4^{\circ} \mathrm{C}$ untuk penggunaan selanjutnya.

\section{Pembuatan ekstrak Rumput Kebar Kering di bawah Matahari}

Rumput Kebar segar dikeringkan di bawah sinar matahari $\left(25-30^{\circ} \mathrm{C}\right)$ selama 7 hari. Setiap pagi rumput dijemur dan sore hari rumput dipindahkan di ruangan tertutup. Setelah 7 hari, sebanyak 50 gr rumput kebar yang telah dijemur dijadikan bubuk menggunakan blender. Bubuk direndam dalam 400 $\mathrm{ml}$ air lalu diinkubasi pada suhu $90^{\circ} \mathrm{C}$ selama 2 jam. 
Setelah dingin, larutan ini kemudian disimpan pada refrigerator suhu $4^{\circ} \mathrm{C}$ untuk penggunaan selanjutnya.

\section{Penyiapan Sampel Feses}

Sampel feses yang akan digunakan dalam pengujian ini adalah sampel feses sapi yang terinfeksi cacing nematoda. Pada tahapan survei awal, feses sapi diambil dari rektum melalui palpasi rektal, lalu dimasukkan ke dalam tabung berisi formalin $10 \%$ untuk tujuan pemeriksaan ada tidaknya telur cacing nematoda dengan metode natif (lokasi pengambilan sampel feses yang jauh). Sampel feses sapi yang positif mengandung telur cacing nematoda selanjutnya dikoleksi ulang tanpa menggunakan formalin $10 \%$, kemudian simpan pada suhu kamar untuk kepentingan perlakuan, kontrol positif, dan kontrol negatif.

\section{Aplikasi ekstrak rumput kebar dalam penghambatan perkembangan telur cacing nematoda}

Aplikasi rumput kebar dalam penghambatan perkembangan telur cacing nematoda dibagi dalam 3 perlakuan (ekstrak rumput kebar segar, ekstrak rumput kebar kering angin, dan ekstrak rumput kebar kering jemur). Pengulangan sebanyak 3 kali pada setiap sampel sehingga jumlah sampel yang diberi perlakuan sebanyak 9 sampel ditambah masingmasing sebanyak 1 kontrol positif dan 1 kontrol negatif sebagai pembanding.

1. Perlakuan : Setiap ekstrak rumput kebar $16 \mathrm{ml}$ (segar, kering angin, kering jemur) dicampur dengan 3 gram feses sapi yang positif mengandung telur cacing nematoda.

2. Kontrol positif: Sebanyak 1 gram oxfendazole dicampur dengan $8 \mathrm{ml}$ air dan 3 gram feses.
3. Kontrol negatif dengan metode kultur larva (pupukan larva) :

Sampel tinja dimasukkan ke dalam cawan atau nampan dan tambahkan vermiculate atau dapat diganti dengan arang atau serbuk kayu yang gunanya untuk menjaga kelembaban dengan perbandingan $1: 1$ kemudian diaduk hingga campurannya kelihatan halus dan merata sambil diberi air secukupnya agar pupukan larva menjadi lembab tetapi tidak basah. Selanjutnya campuran tersebut dimasukkan ke dalam botol selai atau cawan petri dan ratakan permukaannya sambil ditekan perlahan hingga kelihatan agak padat, kemudian bersihkan dinding botol bagian atas permukaan pupukan dari sisa kotoran yang menempel menggunakan kapas/tissue, selanjutnya botol tersebut ditutup agak longgar dan diberi label. Pupukan larva simpan pada suhu kamar dan tidak kena sinar matahari langsung selama 7 - 9 hari, setiap 2-3 hari sekali pupukan larva tersebut dilihat/diperiksa agar kelembabannya terjaga dan bila kelihatan agak kering tambahkan air secukupnya dengan cara disemprot menggunakan hand spray. Ketiga sampel perlakuan, kontrol positif dan negatif disimpan pada suhu ruang selama 7 hari. Pada hari ke 7 dilakukan pengamatan perkembangan larva.

4. Pemanenan kultur larva :

Pemisahan larva infektif dari feses dilakukan dengan Metode Baermann (Gibbons et $a l ., 2014)$ yang telah dimodifikasi, yaitu sebuah corong kaca dimasukkan ke dalam gelas kerucut berisi air yang hampir penuh. Pada mulut corong kaca di atasnya diletakkan feses sapi yang telah dikultur selama 7 hari. Feses 
dibiarkan terendam pada corong kaca selama 30 menit. Larva akan turun dengan sendirinya pada air di dalam gelas. Larva yang berada di dasar gelas diambil menggunakan pipet kemudian diteteskan pada object glass ditutup dengan kaca penutup dan diamati di bawah mikroskop.

\section{Analisis data}

Data yang diperoleh kemudian dianalisis secara tabulasi dan deskriptif.

\section{Hasil dan Pembahasan}

Penelitian efek ekstrak air rumput Kebar sebagai penghambat perkembangan telur cacing gastrointestinal ruminansia secara in vitro dilakukan pada 3 kelompok perlakuan dengan masing-masing 3 kali replikasi. Kelompok 1 perlakuan feses yang mengandung telur cacing direndam dengan ekstrak air rumput kebar segar (50 gram rumput dengan $200 \mathrm{ml}$ air), kelompok 2 perlakuan feses yang mengandung telur cacing direndam dengan ekstrak air rumput kebar kering angin (50 gram dengan $400 \mathrm{ml}$ air), kelompok 3 perlakuan feses yang mengandung telur cacing direndam dengan ekstrak air rumput Kebar kering jemur matahari (50 gram dengan $400 \mathrm{ml}$ air). Sebagai kontrol negatif larva cacing diperoleh dari hasil pemupukan larva pada feses, sebagai kontrol positif feses yang mengandung telur cacing direndam dalam obat cacing oxfendazol. Dalam penelitian penghambatan perkembangan telur cacing ini, pengamatan dan pencatatan hasil pengamatan dilakukan setiap hari selama 7 sampai 9 hari. Telur cacing nematoda pada saluran gastrointestinal ruminansia akan mengalami perkembangan pada lingkungan dan feses kemudian menetas menjadi larva pada hari ke 7 (Kosasih, 2003).

Sampel feses yang digunakan dalam penelitian ini adalah feses sapi yang telah diperiksa terlebih dahulu dengan metode natif. Hasil pemeriksaan natif menunjukkan sampel feses positif mengandung telur cacing nematoda. Adapun tahapan dalam penelitian ini dapat dilihat pada Gambar 1 - 4.

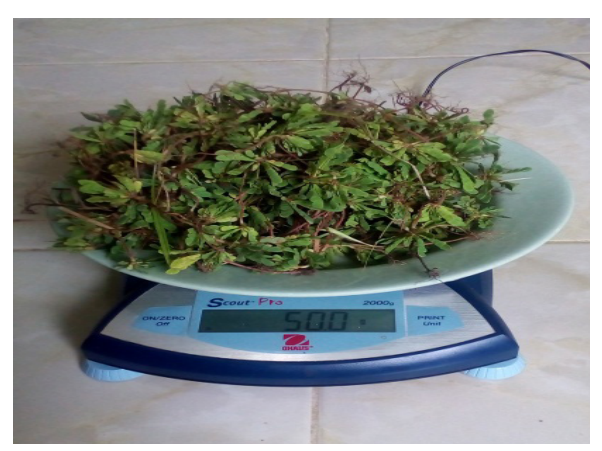

Gambar 1. Rumput Kebar Segar

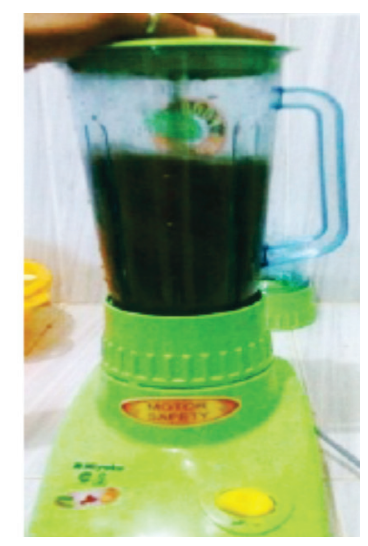

Gambar 2. Penghalusan Rumput Kebar Menggunakan Blender

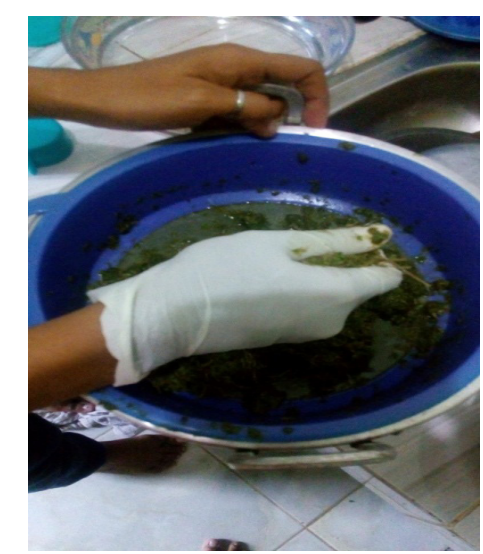

Gambar 3. Penyaringan Ekstrak Segar Rumput Kebar 


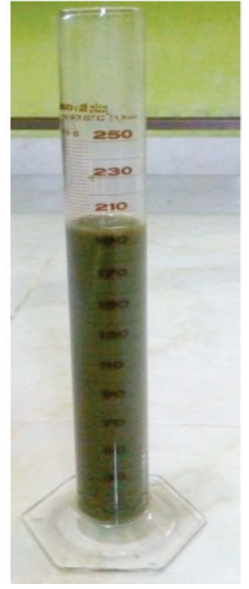

Gambar 4 Sediaan Ekstrak Segar Rumput Kebar

Proses pembuatan ekstrak rumput kebar kering angin dan kering jemur pada penelitian ini ditampilkan pada Gambar 05 sampai 07.
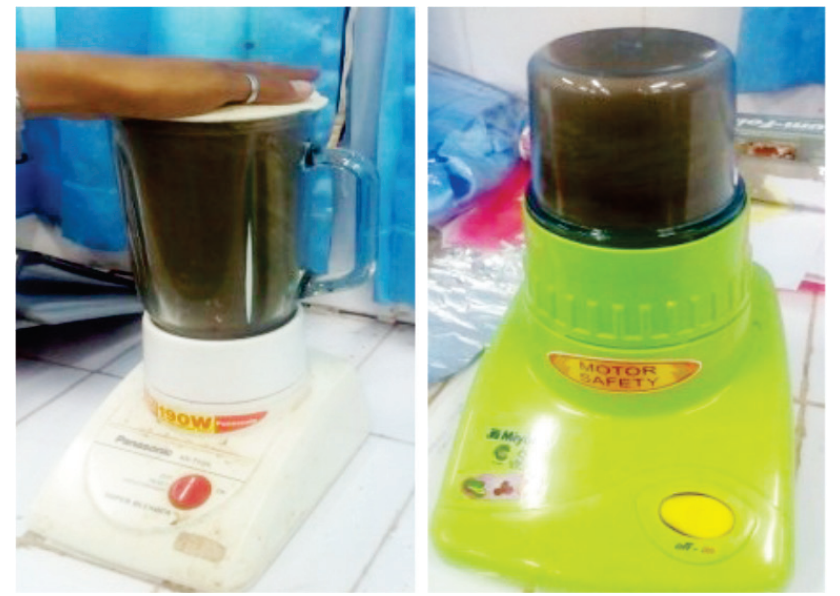

Gambar 5. Penghalusan Rumput Kebar

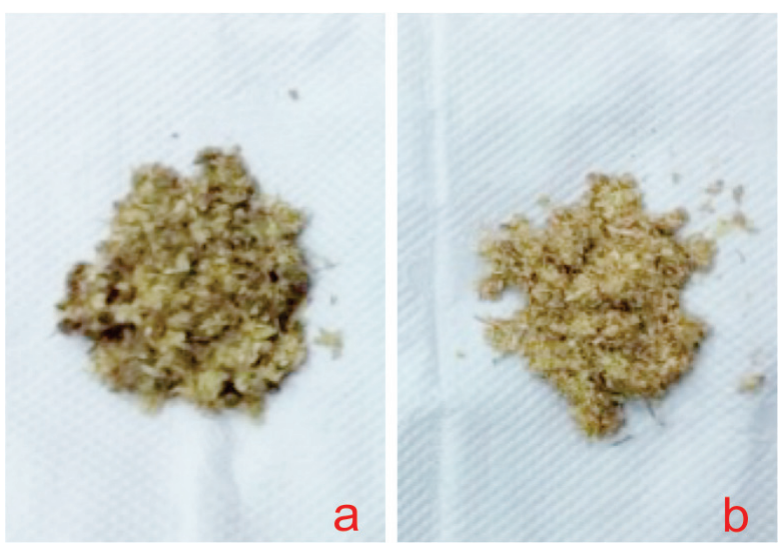

Gambar 6. Serbuk Rumput Kebar Kering (a) kering angin; (b) kering jemur

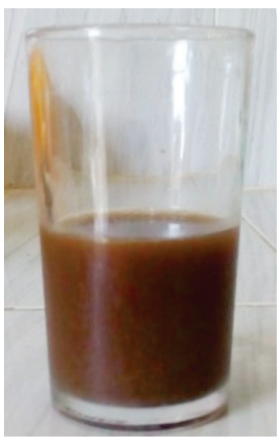

Gambar 7. Ekstrak rumput Kebar kering

Aplikasi ekstrak rumput kebar terhadap telur cacing nematoda, kontrol positif dan kontrol negatif ditampilkan pada Gambar 08.

Hasil pengamatan dari aplikasi ekstrak rumput kebar terhadap perkembangan telur cacing nematoda gastrointestinal sapi dapat dilihat pada Tabel 1.

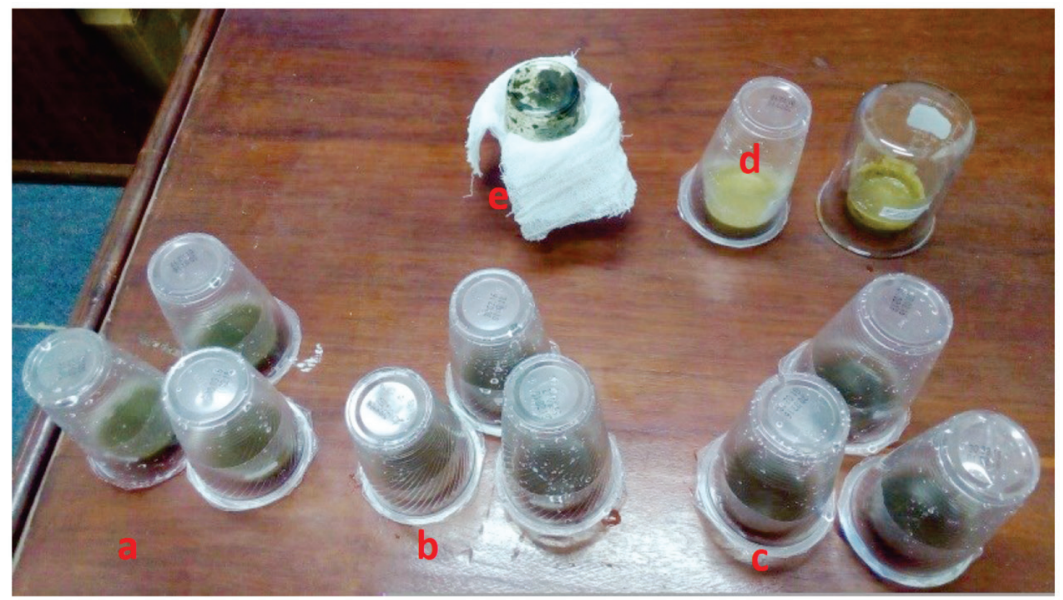

Gambar 8. a-c. Aplikasi ekstrak rumput kebar terhadap telur cacing nematoda d. Kontrol positif (Oxfendazole) e. Kultur larva cacing 
Tabel 1. Hasil pengamatan perkembangan telur cacing nematoda

\begin{tabular}{|c|c|c|c|c|c|c|c|c|}
\hline \multirow{2}{*}{ Perlakuan } & \multicolumn{7}{|c|}{ Pengamatan hari ke } & \multirow{2}{*}{ Keterangan } \\
\hline & 1 & 2 & 3 & 4 & 5 & 6 & 7 & \\
\hline \multicolumn{9}{|c|}{ Ekstrak air rumput kebar segar } \\
\hline Replikasi 1 & - & - & - & - & - & - & + & $\begin{array}{l}\text { Ada telur cacing (tipe Strongyl) tapi tidak berkembang (embrio } \\
\text { di dalam telur tetap segmented dan tidak menetas menjadi } \\
\text { larva sampai hari ke 7) }\end{array}$ \\
\hline Replikasi 2 & - & - & - & - & - & - & - & - \\
\hline Replikasi 3 & - & - & - & - & - & - & - & - \\
\hline \multicolumn{9}{|c|}{ Ekstrak air rumput kebar kering angin } \\
\hline Replikasi 1 & - & - & - & - & - & - & - & - \\
\hline Replikasi 2 & - & - & - & - & - & - & + & Ada telur cacing (tipe Strongyl), tapi tidak berkembang \\
\hline Replikasi 3 & - & - & - & - & - & - & + & Ada telur cacing (tipe Strongyl), tapi tidak berkembang \\
\hline \multicolumn{9}{|c|}{ Ekstrak air rumput kebar kering matahari } \\
\hline Replikasi 1 & - & - & - & - & - & - & - & - \\
\hline Replikasi 2 & - & - & - & - & - & - & - & - \\
\hline Replikasi 3 & - & - & - & - & - & - & - & - \\
\hline \multicolumn{8}{|c|}{ Kontrol positif (Oxfendazole) } & Ada telur cacing (Trichuris sp.) tapi tidak berkembang \\
\hline \multicolumn{8}{|c|}{ Kontrol negatif (kultur larva) } & Ada perkembangan telur cacing menetas menjadi larva cacing \\
\hline
\end{tabular}

Ket. $(+)$ : tidak ada perkembangan telur cacing, $(-)$ : ada perkembangan telur cacing

Pengamatan pada sampel yang diberikan ekstrak air rumput kebar dilakukan setiap hari. Tabel 1 menunjukkan perkembangan telur cacing tipe strongyl dari gastrointestinal sapi dapat dihambat dengan perlakuan ekstrak air rumput kebar segar dan ekstrak air rumput kebar kering angin setelah pengamatan sampai hari ke 7, sehingga tidak dilakukan pemanenan. Telur cacing yang tidak berkembang karena ditambahkan ekstrak rumput kebar segar dan ekstrak rumput kebar kering angin dapat dilihat pada Gambar 9.

Hasil yang diperoleh ini sama seperti pada kontrol positif dengan oxfendazol yang juga dapat menghambat perkembangan telur cacing dari jenis Trichuris sp seperti pada Gambar 10. Berbeda halnya pada kontrol negatif yang mana tidak dilakukan pengamatan setiap hari. Selain itu feses tidak diberi penambahan ekstrak rumput kebar ataupun obat cacing sintetik menunjukkan adanya perkembangan telur cacing dan menetas menjadi larva setelah pengamatan pada hari ke 7 . Larva cacing nematoda dari kontrol negatif dapat dilihat pada Gambar 12.

Dengan demikian, hasil penelitian ini menunjukkan bahwa ekstrak air rumput kebar dan obat cacing oxfendazol memiliki efek dapat menghambat perkembangan telur cacing gastrointestinal sapi. Pada ekstrak air rumput kebar kering jemur matahari tidak ditemukan telur cacing maupun larva cacing setelah 7 hari, hal ini mungkin disebabkan karena jumlah telur cacing yang terlalu sedikit sehingga tidak dapat diamati. Selain itu dapat juga dipengaruhi oleh proses pengeringan rumput kebar dengan paparan sinar matahari langsung ternyata dapat mengurangi bahkan menghilangkan kandungan fitokimia pada tanaman berkhasiat obat (Hernani, 2009). Berdasarkan hasil yang diamati, dapat disimpulkan bahwa pengaruh ekstrak air rumput kebar dapat menghambat perkembangan telur cacing nematoda. 


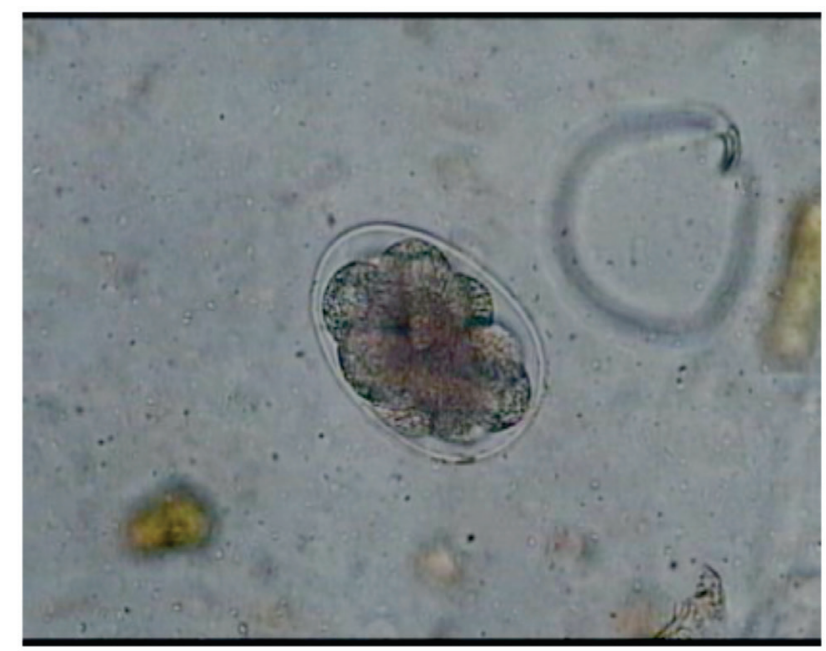

Gambar 9. Telur cacing pada ekstrak rumput Kebar segar \& kering angin (strongyl)

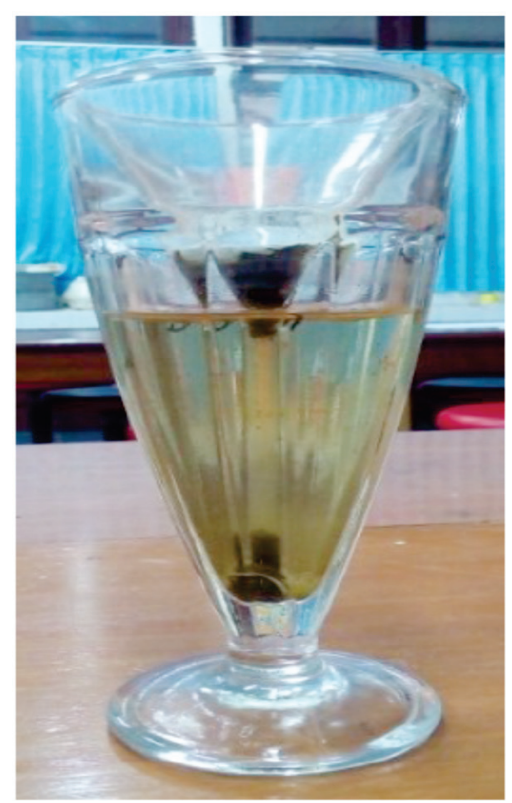

Gambar 11. Pemanenan larva cacing dari kontrol negatif

\section{Kesimpulan}

Penelitian dapat disimpulkan bahwa ekstrak air rumput kebar dapat mempengaruhi penghambatan perkembangan telur cacing nematoda.

\section{Ucapan Terima Kasih}

Penelitian ini dibiayai oleh Direktorat Jenderal Pendidikan Tinggi melalui Penelitian Dosen Pemula.

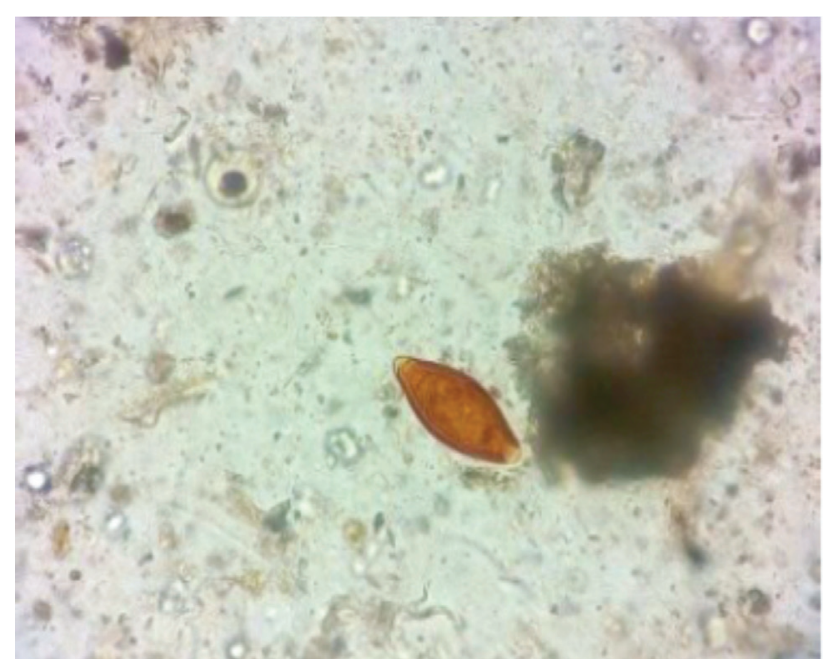

Gambar10. Telur cacing pada kontrol positif (trichuris)

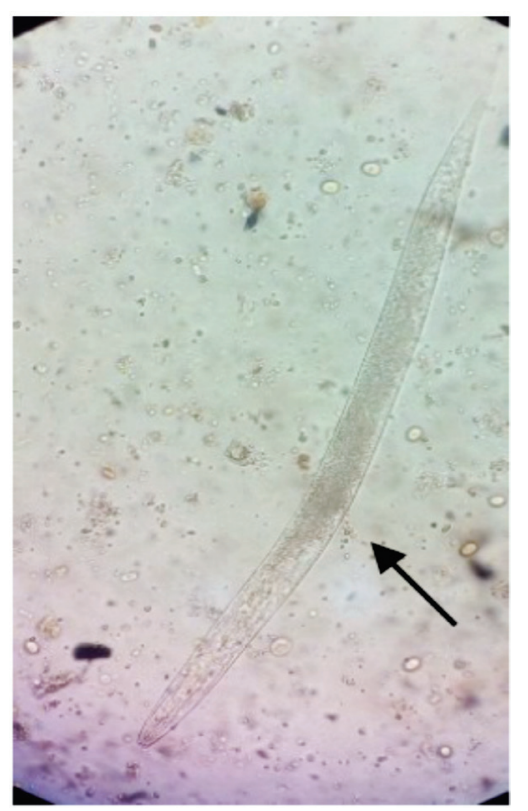

Gambar12. Perkembangan telur cacing menjadi larva

\section{Daftar Pustaka}

Deari Hata Harminda. 2011. Infestasi Parasit Cacing Neoascaris vitulorum pada Ternak Sapi Pesisir di Kecamatan Lubuk Kilangan Kota Padang. Skripsi. Fakultas Peternakan, Universitas Andalas.

Dhewiyanty V, Tri RS dan Ari HY. 2015. Prevalensi dan Intensitas Larva Infektif Nematoda Gastrointestinal Strongylida dan Rhabditida pada Kultur Feses Kambing (Capra, sp.) di Tempat Pemotongan Hewan Kambing Pontianak. Jurnal Protobiont. Vol. 4 (1): 178-183. 
Gibbons LM, Jacobs DE, Fox MT, and Hansen J. 2014. The RVC/FAO Guide to Veterinary Diagnostic Parasitology. Diakses 5 Mei 2017. http:// www.rvc.ac.uk/Review/Parasitology/Index/Index. htm

GrØnhaug TE, Glæserud S, Skogsrud M, Ballo N, Bah S, Diallo D, Paulsen BS. 2008. Ethnopharmacological survey of six medicinal plants from Mali, West-Africa. Journal of Ethnobiology and Ethnomedicine. 4:26.

Hernani dan Nurdjanah R. 2009. Aspek Pengeringan dalam Mempertahankan Kandungan Metabolit Sekunder pada Tanaman Obat. Balai Besar Penelitian dan Pengembangan Pascapanen Pertanian Bogor. Perkembangan Teknologi TRO 21 (2). ISSN 1829-6289. Hal: 33-39.

Hrckova G dan Velebny S.2013. Pharmacological Potential of Selected Natural Compounds in the Control of Parasitic Diseases, SpringerBriefs in Pharmaceutical Science \& Drug Development, DOI: 10.1007/978-3-7091-1325-7_2.

Inngjerdingen KT, Nergard CS, Diallo D, Mounkoro PP, Paulsen BS. 2004. An ethnopharmacological survey of plants used for wound healing in Dogonland, Mali. West Africa. Journal of ethnopharmacology. 92:233244.

Inngjerdingen KT, Coulibaly A, Diallo D, Michaelsen TE, Paulsen BS. 2006. A complement fixing polysaccharide from Biophytum petersianum Klotzsch, a medicinal plant from Mali, West Africa. Biomacromolecules 7:48-53.

Inngjerdingen $\mathrm{M}$, Inngjerdingen $\mathrm{KT}$, Patel TR, Allen S, Chen X, Rolstad B, Morris GA, Harding SE, Michaelsen ET, Diallo D, Paulsen BS. 2008. Pectic polysaccharides from Biophytum petersianum Klotzsch, and their activation of macrophages and dendritic cells. Glycobiology 18(12):1074-1084.

Junaidi M., Sambodo P., Nurhayati D. 2014. Prevalensi Nematoda pada sapi Bali di Kabupaten Manokwari. Jurnal Sain Veteriner
FKH UGM. Vol. 32 No.2.

Kaemmerer, K., Butenkotter, S., 1973. The problem of residuses in meat of edible domestic animals after application or intake of organophosphate esters. Residue Res. 46.1.

Kardel, M., Taube F., Schulz H., Schutze W., and Gierus M. 2013. Different approaches to evaluate tannin content and structure of selected plant extracts-review and new aspects. Journal of Applied Botany and Food Quality 86: 154-166.

Kosasih,Z. 2003. Metode Larval Culture sebagai Teknik Untuk Mengidentifikasi Jenis Cacing Nematoda Saluran Pencernaan pada Ruminansia Kecil. Balai Penelitian Veteriner Bogor. Prosiding Temu Teknis Fungsional Non Peneliti: 74-80.

Munadi. 2011. Tingkat Infeksi Cacing Hati Kaitannya dengan Kerugian Ekonomi Sapi Potong yang disembelih di Rumah Potong Hewan Wilayah Eks-Kresidenan Banyumas. Agripet Vol.11 (1):45-50.

Nofyan E., Kamal M., dan Rosdiana I. 2010. Identitas Jenis Telur Cacing Parasit Usus pada Ternak Sapi (Bos sp.) dan Kerbau (Bubalus sp.) di Rumah Potong Hewan Palembang. Jurnal Penelitian Sains. 10:06-11.

Purwaningsih. 2013. Kajian Lintas seksional dan Analisis Nilai Ekonomi Infestasi Parasit Gastrointestinal pada Pedet di Jawa Tengah. [Thesis]. Yogyakarta: Universitas Gadjah Mada.

Purwanta, Nuraeni, Hutauruk JD. dan Setiawaty S. 2009. Identifikasi Cacing Saluran Pencernaan (Gastrointestinal) pada Sapi Bali melalui Pemeriksaan Tinja di Kabupaten Gowa. Jurnal Agrisistem Vol.5(1):10-21.

Sadsoeitoeboen PD. 2005. Manfaat Ekstrak Rumput Kebar (Biophytum petersianum) terhadap Penampilan Reproduksi Mencit Putih Betina. [Tesis]. Bogor: Institut Pertanian Bogor. 